\title{
Energy analysis to assess the environmental sustainability of the dairy chain
}

\author{
Valentina Giovenzana, Alessandra Fusi, Roberto Beghi, Riccardo Guidetti \\ Department of Agricultural and Environmental Sciences, Production, Landscape and Agroenergy, \\ Università degli Studi di Milano, Italy
}

\begin{abstract}
In the 1990s, attention was focused on saving energy and water with the aim of reducing production costs. Since the turn of this century, problems relating to the management of greenhouse gases have gradually assumed greater importance. Research has highlighted the problems that may arise regarding energy consumption in an Italian dairy chain. Using life-cycle assessment methods, the main steps along the production chain have been identified: breeding, dairy, and food store (FS). Our analysis shows that the different issues involved are often not easily reconcilable. Energy data need to undergo a careful and specific normalization process when dealing with specific data on different parameters $\left(\mathrm{kWh} / \mathrm{t}_{\text {milk }}, \mathrm{kWh} / \mathrm{t}_{\text {milk processed, }} \mathrm{kWh} / \mathrm{m}^{2}{ }_{\text {store }}\right)$. This study examined a variety of production cases ( 2 farms, 2 dairies, and 2 FSs) located in Lombardy, northern Italy, and electric and thermal energy consumption and carbon dioxide emissions were evaluated. A total of $2.8 \mathrm{kgCO}_{2} / \mathrm{kg}_{\text {cheese }}$ carbon dioxide emissions relating to the production process were recorded ( $39 \%$ breeding, $40 \%$ dairy, $1 \%$ FS). Further studies are needed in order to provide consumers with more precise and correct information (carbon labeling or green label). This may become an important element in consumer choice.
\end{abstract}

\section{Introduction}

In 1996, the European Commission adopted Directive no. 96/61 (European Commission, 1996), known as the Integrated Pollution Prevention and Control (IPPC). This was replaced by Directive no.

Correspondence: Riccardo Guidetti, Department of Agricultural and Environmental Sciences, Production, Landscape and Agroenergy, Università degli Studi di Milano, via Celoria 2, 20133 Milano, Italy.

Tel. +39.02.50316870. E-mail: riccardo.guidetti@unimi.it

Key words: sustainability, food chain, greenhouse gases, green label, lifecycle assessment.

Received for publication: 9 May 2012.

Accepted for publication: 10 October 2012.

(C) Copyright V. Giovenzana et al., 2012

Licensee PAGEPress, Italy

Journal of Agricultural Engineering 2012; XLIII:e16

doi:10.4081/jae.2012.e16

This article is distributed under the terms of the Creative Commons Attribution Noncommercial License (by-nc 3.0) which permits any noncommercial use, distribution, and reproduction in any medium, provided the original author(s) and source are credited.
2008/1 (European Commission, 2008) that completed the mandate of the previous directive to prevent and reduce emissions of pollutants derived from various industrial and agricultural activities into the environment.

Later, a series of technical reference documents, known as the Best Available Techniques reference documents (BREF), were drawn up. These techniques are specific for each industrial sector, among which are the food, beverage, and milk industries (Food, Drink, and Milk Industries reference document, FDM BREF) (European Commission, 2006). But these documents do not fully cover certain sectors, such as the wine industry that plays an important role in Italy.

An integrated methodology that allows the energy consumption along the agri-food sector chain to be measured in a transparent and objective manner needs to be identified. While up to now research in these fields has always been limited to assessing only specific steps of the agri-food chain, the methodological innovation of this approach is to start to identify consumption along an integrated process (field to fork). This approach evaluates production from the field to the retailer, and also defines a methodology that can certify products according to energy parameters with the objective of determining the numerical values that could appear on the green label.

This green label will help consumers to choose products that have been produced with the lowest energy consumption or, even better, with the lowest emissions of greenhouse gases (GHGs). Furthermore, it will help manufacturers to produce value-added goods, i.e. those for which production procedures take into account environmental issues. Information concerning these issues could, in fact, influence consumer product choice and, as a consequence, increase the market shares of companies that manufacture environmentally friendly products. Research conducted by Bjørner et al. in 2004 highlighted that the presence of environmental labels on products has a significant effect on consumer choices.

At the moment, different energy labels for food products are being used: Climate Labelling for Food in Sweden (http://www.klimatmarkningen.se/in-english) and the Carbon Label in England (Edwards-Jones et al., 2009). In both cases, the life-cycle assessment (LCA) method represents the basis on which energy consumption and GHG emissions are calculated. LCA is defined as a process to evaluate the environmental burdens associated with a product, process, or activity.

The assessment includes the entire life cycle of the product, process, or activity, encompassing the extraction and processing of raw materials; manufacturing, transportation, and distribution; use, re-use, maintenance, and recycling; and final disposal (Society of Environmental Toxicology and Chemistry, SETAC).

The origins of LCA go back to the 1960s, when concerns over the limitations of raw materials and energy resources led to the development of a method that enabled the resources used to be quantified. In 1969, an internal study was carried out for the Coca-Cola Company. This study aimed to compare different containers in terms of the environmental burden associated with their production. During the 1970s, other companies in both the United States and Europe performed sim- 
ilar comparative LCA studies. Given the growing importance of LCA methodology over the years, standard rules were developed in 1997 by the International Standards Organization (ISO 14040 series) (U.S. Environmental Protection Agency, 2006).

The food sector contributes significantly to environmental impact (Peacock et al., 2011). In order to identify possible directions for sustainable food production and consumption, LCA has been applied for more than 15 years to both agricultural and food systems, and a variety of databases have been developed (Notarnicola, 2011).

In spite of the fact that the LCA method represents a tool that has been generally accepted by the scientific community, some limitations to this methodology can be identified, the main ones being complexity and costs in terms of time and resources (Eide and Ohlsson, 1998; Brentrup et al., 2004; Reap et al., 2008; Brenton et al., 2009; Hospido et al., 2010; Lewandowska et al., 2011).

To overcome the complexity of LCA, some researchers have proposed simplified methods for the car (Hochschorner and Finnveden, 2003) and dairy (Eide and Ohlsson, 1998) sectors.

The food industry uses energy to grow raw materials so it is also necessary to consider the fixed $\mathrm{CO}_{2}$ during the life of plants. Other energy uses in this sector involve processing, the transport of raw materials and finished products to food stores (FSs), and for storage and packaging operations. In addition, compared to other industries, this is a very heterogeneous sector with a wide range of sizes and types of business using a variety of raw materials and processes, not to mention the natural variability that characterizes crop cultivation.

The application of LCA to the agro-food sector is complex due to the nature of the production process itself. Although modern technology companies can be compared to industrial systems, some specific aspects of the field must be taken into account.

Depending almost exclusively on human control, the production process is easier to compare with standard industry processes. On the contrary, agriculture could be viewed as a combination of natural phe-

Table 1. General data of analyzed companies.

\begin{tabular}{lccc}
$\begin{array}{l}\text { Company } \\
\text { type }\end{array}$ & $\begin{array}{c}\text { No. dainy } \\
\text { cows }\end{array}$ & Milk & Area \\
Breeding farm 1 & 350 & $3300 \mathrm{t}_{\text {milk }} /$ year & - \\
Breeding farm 2 & 200 & $1500 \mathrm{t}_{\text {milkyear }}$ & - \\
\hline Dairy 1 & - & $541 \mathrm{t}_{\text {processed milk }} /$ year & - \\
Dairy 2 & - & $250 \mathrm{t}_{\text {processed milk/year }}$ & - \\
\hline FS 1 & - & - & $3200 \mathrm{~m}^{2}$ \\
FS 2 & - & - & $5000 \mathrm{~m}^{2}$ \\
\hline
\end{tabular}

FS, food store. nomena and industrial processes that can be driven but not completely controlled by humans.

So it is important to establish an evaluation method that can accurately observe natural phenomena and human activities. This problem has already been considered in the past (Audsley et al., 1997; Williams et al., 2005; Blengini and Busto, 2009) but it is important to have practical feedback. We, therefore, studied cheese production, a typical Italian integrated agri-food chain.

\section{Materials and methods}

In this study, 6 separate companies were analyzed in terms of energy consumption: 2 dairy cow breeding farms, a dairy that produces mature cheese (Parmigiano Reggiano), a dairy that produces fresh and semifresh cheese, and 2 FSs.

The main characteristics of each type of company considered in the analysis are (Table 1):

- for breeding farms, the number of cows and the amount of milk produced annually;

- for dairies, the amount of milk processed annually;

- for FSs, the total area occupied.

Table 2 shows the three phases of energy analysis that were examined. For each company, the electrical and thermal energy consumption was analyzed for both the production processes and the management of the company. In particular, the following were included:

- for breeding farms: energy consumption in stables, cattle feed production, milking room, office, milk storage room, illumination, etc.;

- for dairies: energy consumption for cheese production (pasteurization, curd cooking, packaging, etc.), office, illumination, etc.;

- for FSs: energy consumption for illumination, air-conditioning, packaging, refrigeration, etc.

The estimated data, following the census of electrical and thermal properties, were compared with those presented in the energy bills, which confirmed the estimated data. The estimates of $\mathrm{CO}_{2}$ emissions in relation to electricity consumption are calculated using the Italian emission factor of $0.410 \mathrm{~kg} \mathrm{CO} / \mathrm{kWh}$ (ISPRA, 2011) that represents the index of emissions of carbon dioxide calculated considering average electricity production in Italy. The estimated $\mathrm{CO}_{2}$ emissions due to fuel consumption are calculated as per European Commission Directive no. 2008/101 (European Commission, 2008).

Data normalization was performed considering the specific data referred to a ton of cheese for each phase of the chain:

- breeding: productiveness of the milk-yield cheese was evaluated (Table 3) by differentiating the type of product (mature cheese, $7.5 \%$, or soft cheese, $15 \%)$;

Table 2. Energy analysis.

\begin{tabular}{|c|c|}
\hline Type of analysis & Data collected \\
\hline Documents analysis & Collection of data from bills: productivity, electricity, water and fuel consumptions, reported for the same year of production. \\
\hline Business analysis & Obtain the outputs and times of use of all electrical and thermal utilities in the company. \\
\hline Report & $\begin{array}{l}\text { Flow sheet of process with energy data; } \\
\text { Identification and quantification of energy flows in and out; } \\
\text { Disequilibrium of energy (critical energy points); } \\
\text { Distribution of consumption across business departments; } \\
\text { Accounting of specific energy value (kWh/t of product) and emissions of carbon dioxide }\left(\mathrm{CO}_{2} / \mathrm{t} \text { of product). }\right.\end{array}$ \\
\hline
\end{tabular}


- dairy: the simplest to analyze since the data obtained already refer to the amount of cheese;

- FSs: only the energy consumption attributable to the refrigerated display cases for the cheese (consumption related to lighting and refrigeration plant) was considered. Data obtained are reported in Table 4.

\section{Results and discussion}

Emissions associated with electricity and fuel consumption were normalized to the ton of product in order to provide an emissivity index ( $\mathrm{kg} \mathrm{CO}_{2} / \mathrm{t}$ of product) that could be compared to data in the literature.

The results were compared with reference data provided by best available techniques (BAT) (Table 5) or literature in order to verify whether the company is in line with European indications and, on the other hand, to identify the most appropriate interventions to improve energy use in the production process.

Table 3. Productiveness of the milk-cheese transformation.

\begin{tabular}{lc} 
Company & Transformation productiveness \\
Dairy 1 & $7.5 \%$ \\
Dairy 2 & $15 \%$ \\
\hline
\end{tabular}

Table 4. Energy characteristics of display cases for the cheeses in food stores.

\begin{tabular}{lcc}
\hline Energy characteristics & FS1 & FS2 \\
Area dedicated to cheese sales $\left(\mathrm{m}^{2}\right)$ & 22 & 34 \\
Cheese sold (t/year) & 935 & 1584 \\
\hline Consumption electricity $(\mathrm{kWh} /$ /year) & 13,574 & 27,880 \\
Consumption thermal energy $(\mathrm{kWh} /$ year $)$ & 2750 & 4182 \\
\hline FS, food store. & &
\end{tabular}

Table 5. Best available technique reference values for consumption related to milk processing.

\begin{tabular}{lc} 
BAT & $\mathrm{kWh} / \mathrm{t}$ processed millk \\
Consumption electricity & $22.2-805.6$ \\
Consumption thermal energy & $41.7-1277.8$ \\
\hline BAT, best available technique.
\end{tabular}

More specifically, for the breeding farms, the comparison of energy consumption was only possible per head of cattle bred $(\mathrm{kWh} /$ head of cattle a day $)$ or per ton of milk produced $(\mathrm{kWh} /$ milk $)$. However, in this case, the reference value was not available for comparison. The reference for the dairy was a ton of processed milk for consumption $\left(\mathrm{kWh} / \mathrm{t}_{\text {processed milk }}\right)$ or cheese produced ( $\left.\mathrm{kg} \mathrm{CO}_{2} / \mathrm{kg}_{\text {cheese }}\right)$. Finally, for the FSs it was possible to compare the energy consumed on the basis of the size of the store $\left(\mathrm{kWh} / \mathrm{m}^{2}\right.$ store) (Table 6). Also in this case, the reference value was not available.

For the breeding farms, it was only possible to make a comparison of consumption of electricity per head of cattle. Breeding Farm 1 has a specific consumption of electricity equal to $1.99 \mathrm{kWh}$ per head of cattle per day, while for the Breeding Farm 2 this is approximately $2.2 \mathrm{kWh}$ per head of cattle per day. The data found in the literature indicate values between 0.8 and $1.6 \mathrm{kWh}$ per head of cattle per day; in both cases, therefore, the specific consumption is slightly higher than the values used for comparison (Regione Piemonte, 2003).

It is also important to note the wide range of reference. It is easier for a company to be environmentally friendly in terms of consumption if the range is wide; the energy consumption of the dairy must fall between 22 and $806 \mathrm{kWh}_{\mathrm{e}}$ for consumption of electricity and between 47.7 and $1279 \mathrm{kWh}_{\mathrm{t}}$ for consumption of thermal energy.

The results for Dairy 1 are within the range proposed by BAT; more specifically, both consumption of electricity and thermal energy are nearer the lower limit. Diary 2 presents higher results (always in the BAT range). This difference between the two dairy companies is due to the type of cheese produced (fresh or mature, respectively).

Furthermore, the goal is to determine the energy cost and environmental impact of the integrated process of the cheese production in terms of $\mathrm{kWh}$ and $\mathrm{kgCO}_{2}$ per ton of cheese produced. To do that it was necessary to carry out a series of normalizations.

From the parameters mentioned in Table 6, and subject to revision, it was possible to calculate the standard fuel consumption and emissions per ton of cheese or sales for FS (Table 7).

The energy consumption associated with the production of cheese corresponds to approximately $6.55 \mathrm{kWh} / \mathrm{kg}$, which is equivalent to approximately $23.58 \mathrm{MJ} / \mathrm{kg}$. This value falls within the wide range of comparison for the European countries found in the literature: 2.1 to 68 $\mathrm{MJ} / \mathrm{kg}$ of cheese (Xu et al., 2009). The main factors influencing the dairies' energy consumption are the size of the production structure, the type of cheese (with or without a maturing process), and the technology used, as well as the age of the plant, machinery efficiency, and efficiency of fuel used.

Regarding the whole dairy chain studied, the total $\mathrm{CO}_{2}$ emissions were found to be $2800 \mathrm{kgCO} / \mathrm{t}_{\text {cheese }}$.

The major contribution comes from dairy companies (1693 $\left.\mathrm{kgCO}_{2} / \mathrm{t}_{\text {cheese }}\right)$ while, in contrast, FSs have an almost irrelevant impact on $\mathrm{CO}_{2}$ emissions.

Table 6. Summary of consumption of electricity and thermal energy and $\mathrm{CO}_{2}$ emissions relating to production year and specific reference. $\mathrm{CO}_{2}$ emissions are the sum of electricity and thermal energy consumption.

\begin{tabular}{|c|c|c|c|c|c|c|c|c|c|}
\hline \multirow[t]{2}{*}{ Company } & \multicolumn{3}{|c|}{$\begin{array}{l}\text { Yearly consumption } \\
\text { and emission }\end{array}$} & \multicolumn{3}{|c|}{$\begin{array}{c}\text { Specific consumption } \\
\text { and emission }\end{array}$} & \multicolumn{3}{|c|}{$\begin{array}{l}\text { Reference } \\
\text { value }\end{array}$} \\
\hline & $\mathrm{kWh}_{\mathrm{e}}$ & $\mathrm{kWh}_{\mathrm{t}}$ & $\mathrm{kgCO}_{2}$ & $\mathrm{kWh}_{\mathrm{e}}$ & $\mathrm{kWh}_{\mathrm{t}}$ & $\mathrm{kgCO}_{2}$ & $\mathrm{kWh}_{\mathrm{e}}$ & $\mathrm{kWh}_{\mathrm{t}}$ & $\mathrm{kgCO}_{2}$ \\
\hline Breeding farm 1 & 253,710 & 316,111 & 212,770 & $77 \mathrm{t}_{\text {milk }}$ & $95 \mathrm{t}_{\text {milk }}$ & $64 \mathrm{t}_{\text {milk }}$ & n.a. & n.a. & n.a. \\
\hline Breeding farm 2 & 160,570 & 133,556 & 91,580 & $105 \mathrm{t}_{\text {milk }}$ & $90 \mathrm{t}_{\text {milk }}$ & $60 \mathrm{t}_{\text {milk }}$ & n.a. & n.a. & n.a. \\
\hline Dairy 1 & 448,630 & $2,674,620$ & 496,830 & $60 \mathrm{t}_{\text {processed milk }}$ & $355 \mathrm{t}_{\text {processed milk }}$ & $0.9 \mathrm{~kg}_{\text {cheese }}$ & $22-806 \mathrm{t}_{\text {processed milk }}$ & $41.7-1279 t_{\text {processed milk }}$ & $0.317 \mathrm{~kg}_{\text {cheese }}$ \\
\hline Dairy 2 & 104,340 & 189,444 & 93,550 & $417.36 \mathrm{t}_{\text {processed milk }}$ & $757.78 \mathrm{t}_{\text {processed milk }}$ & $2.5 \mathrm{~kg}_{\text {cheese }}$ & $22-806 t_{\text {processed milk }}$ & $41.7-1279 t_{\text {processed milk }}$ & $0.317 \mathrm{~kg}_{\text {cheese }}$ \\
\hline FS 1 & $1,973,844$ & 400,000 & 92,057 & $617 \mathrm{~m}_{\text {store }}^{2}$ & $125 \mathrm{~m}_{\text {store }}^{2}$ & $29 \mathrm{~m}_{\text {store }}^{2}$ & n.a. & n.a. & n.a. \\
\hline FS 2 & $4,098,223$ & 615,560 & 142,184 & $820 \mathrm{~m}^{2}$ store & $123 \mathrm{~m}_{\text {store }}^{2}$ & $28 \mathrm{~m}^{2}$ store & n.a. & n.a. & n.a. \\
\hline
\end{tabular}

FS, food store; n.a., not available. 
Table 7. Specific consumptions and emissions resulting from the normalization of the quantity of cheese (produced or sold).

\begin{tabular}{lcccc} 
& $\begin{array}{c}\text { Specific } \\
\text { consumption } \\
\text { electricity }\end{array}$ & $\begin{array}{c}\text { Specific } \\
\text { consumption } \\
\text { thermal energy }\end{array}$ & $\begin{array}{c}\text { Specific emission } \\
\text { (electric energy) }\end{array}$ & $\begin{array}{c}\text { Specific emission } \\
\text { (thermal energy) }\end{array}$ \\
\hline Unit of measurement & 1533 & 2418 & 743 & 360 \\
Breeding farm & 1791 & 4762 & 869 & 824 \\
Dairy & 5.3 & n.a. & 2.6 & n.a. \\
\hline FS & 3329 & 7181 & 1615 & 1184 \\
Total & & & & \\
\hline FS, food store; n.a., not available. & & & & \\
\end{tabular}

The case studies analyzed identified the practical problems that can arise during the realization of an energy analysis.

The issues involved concern the calculation of $\mathrm{CO}_{2}$ fixed during the cultivation of plants, which in most cases represent the raw material in the agro-food industry. Separating farming from processing sometimes compromises the integration of these data.

Transport is a very critical phase of the integrated plant. First, if we talk about imports and exports, we must consider the fact that every country has its coefficients (ISPRA, 2011) for calculating the $\mathrm{CO}_{2}$ emissions. In a study carried out by Edwards-Jones et al. (2009), GHG emissions deriving from food transport were calculated. The results highlighted the energy savings achieved when internally produced food products are consumed with respect to the consumption of imported food. Nevertheless, it must be considered that emissions from transport can be more than compensated for by efficiencies in other stages of the production and distribution. Geographical location alone is a poor proxy for total emissions: concepts such as food miles can in fact be misguiding since they cannot reflect the complexity of carbon emissions (Brenton et al., 2009).

\section{Conclusions}

The energy requirements of a food chain such as that of dairy products are particularly complex because of the variability of the phases in the production chain.

The most appropriate method for evaluating various types of production is to perform an energy analysis to obtain a picture of the company's energy consumption and to intervene to correct any critical aspects.

In order for there to be an energy label (green label) on the packaging of the final product, there must be a common evaluation method that is respected and that could possibly also come under the supervision of a certifying body.

It is also important to identify the person responsible for drawing up a label that includes all consumption and emissions of the integrated process analyzed; this could be a representative of product marketing.

Another problem is the lack of official comparative data to assess the capacity of the company in terms of environmental impact, which should be encouraged at a national level in order to quantify these integrated values.

This work aims to highlight the difficulties encountered during the calculation of energy consumption and of $\mathrm{CO}_{2}$ emissions. It is a fundamental starting point for understanding the problems that need to be solved and contributes to a number of requirements that the market has begun to propose. The final objective (quantification of the $\mathrm{CO}_{2}$ emitted by the integrated chain) is still a long way off, especially considering the diversity of the agro-food sector. Consumers still do not really come into contact with the reality of the food industry such as dairies rather than breeding, but they do have a continuous relationship with the FSs (mass distribution). This could be critical in the campaign to raise consumer awareness of energy and environmental issues.

\section{References}

Audsley E., Alber S., Clift R., Cowell S., Crettaz P., Gaillard G., Hausheer J., Jolliett O., Kleijn R., Mortensen B., Pearce D., Roger E., Teulon H., Weidema B., Zeits H. 1997. Harmonisation of environmental life cycle assessment for agriculture. Final report of EU Concerted Action AIR3-CT94-2028. European Commission DG VI Agriculture, Brussels, p 103.

Bjørner T.B., Hansen L.G., Russell C.S. 2004. Environmental labeling and consumers' choice-an empirical analysis of the effect of the Nordic Swan. J. Environ. Econ. Manage. 47: 411-34.

Blengini G.A, Busto M. 2009. The life cycle of rice: LCA of alternative agri-food chain management systems in Vercelli (Italy). J. Environ. Manage. 90:1512-22.

Brenton P., Edwards-Jones G., Jensen M.F. 2009. Carbon labelling and low-income country exports: a review of the development issues. Dev. Pol. Rev. 27:243-67.

Brentrup F., Kusters J., Kuhlmann H., Lammel J. 2004. Environmental impact assessment of agricultural production system using the life cycle assessment methodology tailored o crop production. Eur. J. Agron. 20:247-64.

Edwards-Jones G., Plassmann K., York E.H., Hounsome B., Jones D.L., Mila I., Canals L. 2009. Vulnerability of exporting nations to the development of a carbon label in the United Kingdom. Environ. Sci. Pol. 12:479-90.

Eide M.H., Ohlsson T. 1998. A comparison of two different approaches to inventory analysis of dairies. Int. J. Life Cycle Assess. 3:209-15.

European Commission. 1996. Integrated pollution prevention and control (IPPC), Directive no. 96/61/EC. In: Official Journal of the European Union, L 257, 24/09/1996, pp 26-40.

European Commission. 2008. Integrated pollution prevention and control (IPPC), Directive no. 08/01/EC. In: Official Journal of the European Union, L 24, 15/01/2008, pp 08-29.

European Commission (Joint Research Center). 2006. Reference document on best available techniques in the food, drink and milk industries (BREFs 08.2006), Annex 1, part 6.4, (b) and (c) of Council Directive no. 96/61. In: Official Journal of the European Union, L 257, 24/09/1996, pp 26-40. Available from: http://eippcb.jrc. es/reference/

European Commission. 2008. Scheme for greenhouse gas emission allowance trading within the Community and amending Directive 2003/87/EC. Council Directive no. 2008/101/EC. In: Official Journal 
of the European Union, L 8, 19/11/2008, pp 3-21.

Hochschorner E., Finnveden G. 2003. Evaluation of two simplified life cycle assessment methods. Int. J. Life Cycle Assess. 8:119-28.

Hospido A., Davis J., Berlin J., Sonesson U. 2010. A review of methodological issues affecting LCA of novel food products. Int. J. Life Cycle Assess. 15:44-52.

ISPRA (Istituto Superiore per la Protezione e Ricerca Ambientale). 2011. Produzione termoelettrica ed emissioni di $\mathrm{CO}_{2}$, Fonti rinnovabili e impianit soggetti a ETS. 9487 Rapporto 135 2011. Available from: http://www.isprambiente.gov.it/contentfiles/00009400/9486rapporto-135-2011.pdf

Lewandowska A., Matuszak-Flejszman A., Joachimiak K., Ciroth A. 2011. Environmental life cycle assessment (LCA) as a tool for identification and assessment of environmental aspects in environmental management systems (EMS) Part 2: case studies. Int. J. Life Cycle Assess. 16:247-57.

Notarnicola B. 2011. 7th International Conference on Life Cycle Assessment in the Agri-Food Sector (LCA Food 2010), 22-24 September 2010, Bari (Italy). Int. J. Life Cycle Assess. 16:102-5.

Peacock N., De Camillis C., Pennington D., Aichinger H., Parenti A., Rennaud J., Raggi A., Brentrup F., Sára B., Schenker U., Unger N.,
Ziegler F. 2011. Towards a harmonised framework methodology for the environmental assessment of food and drink products. Int. J. Life Cycle Assess. 16:189-97.

Reap J., Roman F., Duncan S., Bras B. 2008. A survey of unresolved problems in life cycle assessment Part 1: goal and scope and inventory analysis. Int. J. Life Cycle Assess. 13:290-300.

Regione Piemonte. 2003. Il consumo energetico delle aziende agricole: rilevamento, analisi e ottimizzazione. Quaderni della Regione Piemonte, Agricoltura e sviluppo rurale, n. 15/99. Available from: http://www.regione.piemonte.it/agri/comunicazione/quaderni

U.S. Environmental Protection Agency. 2006. 2006-2011 EPA strategic plan - Charting our course. September 30, 2006. U.S. Environmental Protection Agency, Washington, DC, USA. Available from: http://nepis.epa.gov/Adobe/PDF/P1001IPK.PDF

Williams A.G., Audsley E., Sandars D.L. 2005. Final report to Defra on Project IS0205: determining the environmental burdens and resource use in the production of agricultural and horticultural commodities. Department of Environment, Food, and Rural Affairs (Defra), London.

Xu T., Flapper J., Kramer K. J. 2009. Characterization of energy use and performance of global cheese processing. Energy 34:1993-2000. 